\title{
Altered gastrointestinal mucosal permeability in asthma
}

\author{
John Walker ${ }^{\text {** }}$ D Mah¹, Kyunh Park1', L Dieleman', J Meddings², DP Vethanayagam \\ From Canadian Society of Allergy and Clinical Immunology Annual Scientific Meeting 2010 \\ Victoria, Canada. 3-6 November 2010
}

\section{Background}

Abnormal gastrointestinal permeability (GIP) has been implicated in immunologic disease, including Crohn's disease and celiac disease, but also including non-intestinal diseases such as diabetes and multiple sclerosis. Abnormal GIP may lead to entry of allergens from the gut into the systemic circulation and may prime the immune system, inciting inflammation outside the gut.

\section{Hypothesis}

Adult asthmatics demonstrate abnormal small bowel GIP.

\section{Methods}

GIP in ten patients followed in a regional referral centre in Northern Alberta was assessed. Patients were classified as allergic versus non-allergic on the basis of skin allergen testing. GIP was evaluated using an assay with established normal range values. Patients ingested a solution containing sucrose, mannitol and lactulose and urine was collected and assayed using high-performance liquid chromatography. Retrospectively, patient records were reviewed, and in addition to demographics, airway physiology, atopy, and sputum cell counts (SCCs) were captured.

\section{Results}

5 of 10 patients had increased GIP (Figure 1). Patients with abnormal GIP were not more likely to have evidence of active airway inflammation as assessed by SCC. There was no association between atopy and abnormal GIP.

\footnotetext{
* Correspondence: jwalker@ualberta.ca

'Department of Medicine and Pulmonary Research Group, University of Alberta, Edmonton, Alberta, Canada

Full list of author information is available at the end of the article
}

\section{Discussion}

This study demonstrates an increase in GIP in the MALTrich small intestine of asthmatic patients, illustrating an association between abnormal GIP and current asthma.

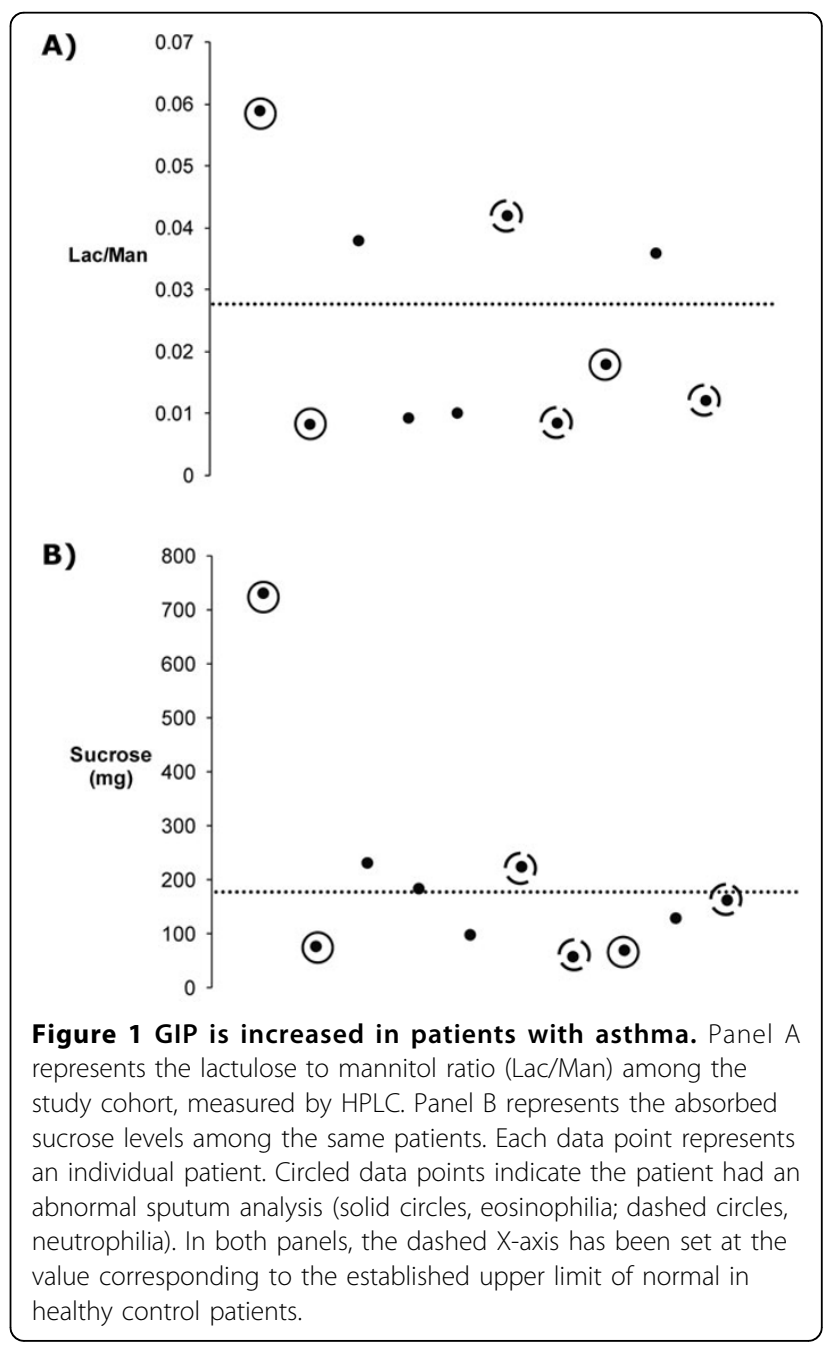


Abnormal GIP did not correlate with concurrent airway inflammation. Abnormal GIP may be an important determinant of allergenic entry into the systemic circulation, and the absence of a correlation between active airway inflammation and increased GIP suggests a primary defect in the immunologic barrier.

\section{Author details}

${ }^{1}$ Department of Medicine and Pulmonary Research Group, University of Alberta, Edmonton, Alberta, Canada. ${ }^{2}$ Department of Medicine, University of Calgary, Calgary, Alberta, Canada.

Published: 4 November 2010

\section{doi:10.1186/1710-1492-6-S2-P15}

Cite this article as: Walker et al: Altered gastrointestinal mucosal permeability in asthma. Allergy, Asthma \& Clinical Immunology 20106 (Suppl 2):P15

Submit your next manuscript to BioMed Central and take full advantage of:

- Convenient online submission

- Thorough peer review

- No space constraints or color figure charges

- Immediate publication on acceptance

- Inclusion in PubMed, CAS, Scopus and Google Scholar

- Research which is freely available for redistribution

Submit your manuscript at www.biomedcentral.com/submit 